\title{
Ng'angas - Zambian Healers-Diviners and their Relationship with Pentecostal Christianity: The Intermingling of Pre- Christian Beliefs and Christianity
}

\section{Agnieszka Podolecka and Austin M. Cheyeka agapod70@gmail.com acheyeka@yahoo.co.uk}

All the separatist churches - and even the African sections of the mission churches - are syncretic... All their Christian ideas are edited by the religious ideas they bring with them from their cultural upbringing

(Vilakazi, Mthethwa, \& Mpanza 1986:156).

\begin{abstract}
The aim of the article is to establish if pre-Christian beliefs in Zambia are influencing the Pentecostal Christianity, and to establish what the healersdiviners' relationship with different Pentecostal churches is. During field studies undertaken by both authors, it has been established that many Bantu speaking people still believe in some aspects of their native religions, especially in the powers of the ancestral spirits. Christianity is the dominant religion in Zambia, but it is far from homogenous. Apart from world religions like Roman Catholicism and Protestantism, there is a plethora of Pentecostal, Charismatic, and grassroot churches, many of them not immune to ancient spirit veneration. People who are believed to cooperate with spirits are called healers-diviners who are believed to be called to their profession by spirits. A great majority is Christian who combines Christianity with their native beliefs. The field studies in 2021 were sponsored by the Polish National Science Centre (Narodowe Centrum Nauki), Poland, project no. 2017/25/N/ HS1/02500.
\end{abstract}


Keywords: $N g$ 'anga, healer-diviner, Zambia, African Traditional Religion (ATR)

\section{Introduction}

Zambia is a landlocked country in Southern Africa, governed by a 150member parliament, with the president as the head of state. Colonized from 1889 to 1991 by the British and called Northern Rhodesia, it gained its independence in October 1964 (Taylor 2006:xv-xvi). Zambia is inhabited by almost 19 million people. There are 73 ethnic groups in this country, most of them of Bantu origins ${ }^{1}$. The first people in this country's territory were San, also called Bushmen ${ }^{2}$. Bantu ethnic groups, which are now dominant in Zambia, displaced the San around 1100 and 1200 (Taylor 2006:11) ${ }^{3}$. Many of the Bantu speaking people who inhabit the country, adhere to Christianity. Indigenous Zambians have a deep religious and spiritual heritage vouchsafed in myths, rituals, and symbols, which Rev Edwin Smith of the Primitive Methodists, in his understanding of the religion of the Ila people of the Southern Province of the country between 1907 and 1915, named the 'African Traditional Religion' (ATR) ${ }^{4}$ and used the term as a title of his book. Today, researchers of pre-Christian religions in Zambia are faced with a major question of how to characterize the Zambian indigenous spiritual traditions, which are diverse and complex among 73 ethnic groups speaking related languages.

Christianity and colonialism had a contemporaneous rise in Zambia. Although some mythology in historical books on Zambia, developed over time, claim that Christianity resulted from the travels, writings, talks, and

1 Nearly $90 \%$ of Zambians belong to one of nine ethnolinguistic groups, NyanjaChewa, Bemba, Tonga, Tumbuka, Lunda, Luvale, Kaonde, Lozi, and Nkoya. The official language is English (World Population Review n.d.)

2 San people have always been hunter-gatherers, strongly connected to nature. Their beliefs have been and still are based on the shamanic perspective of the intermingling of material and spiritual worlds. Currently, their numbers are so small that they are not included in the Zambian census (Census 2010:79).

3 Holmes argues that the first Bantu arrived around 300 CE (Holmes 1998:19-20).

4 The term was popularized by Smith's colleague, Rev Geoffrey Parrinder in his influential book, African traditional religion (Parrinder 1954). 
death in 1873 of a Scots medical doctor, missionary, and explorer in the territory, called David Livingstone, this is not entirely true. While his memorialization may have drawn some missionaries to Zambia, Livingstone himself did little traditional missionary work. He was only a missionary during his first journey (1853-1856) but failed to establish a mission station the most important manifestation of missionary activities, and only managed to convert only one person, Chief Sechele who lived in the present-day Botswana (Mackenzie 1993:74).

The point here is that missionaries who arrived with or slightly after the colonialists, were generally perceived as being one or in cahoots with their counterparts, the colonial masters. From its inception, according to Robert Strayer (1976:1), mission history resorted under the metropolitanecclesiastical school, which focused on European strategies for the planting of Christianity in Africa, and on the heroic missionary efforts to implement these plans. This literature hardly speaks to the theme or encounter of missionary Christianity and the ATR. In this respect, it resembles the early colonial history, which saw Africa as a stage on which Europeans of all kinds played out their interests and their fantasies (Strayer 1976:1). The historical works of two particular iconic Africanist church historians, Andrew Walls (2002, 1996) and Lamin Sanneh $(1989,1993)$ describe the growth of Christianity in Africa in terms of the translation or vernacularization of the Christian message, or to use the current term, 'enculturation' of the Christian message.

According to a 2010 census, over $95 \%$ of Zambian citizens declare themselves Christians, while only $2 \%$ practice native religions called ATR (IHSN 2010). The World Christian Database has published different data: Approximately $83 \%$ people are Christians, while the ATR is practiced by approximately $10 \%$ (ARDA n.d.). The percentage distribution of the population by religious affiliation in the 2010 census of population and housing, indicates that $75.3 \%$ of the Christians in Zambia are Protestant while 20.2\% are Roman Catholic (Census 2010). There is no data on the number of Pentecostal and Charismatic Christians. Their numbers, however, may be included in the Protestant percentage because they have Protestantism as their root. Though the numbers are unknown, one of the most striking salient features of this Christianity is the proliferation of small grassroot churches and the near-constant circulation of their members among these churches (Haynes 2012:xviii). Other world religions also have their followers, like Islam, Hinduism, and Buddhism. Zambia is a tolerant country in terms of 
religion, though in 1996 there were riots against Hindus, and government clashed with Jehovah's witnesses because they refused to salute the national flag and sing the anthem - normal practices for Jehovah's witnesses as they do not engage in politics at all (Taylor 2006:37-38).

The research questions for this article are:

- Who are healers-diviners and how does a person become one? Are they ATR believers, Christians, or non-religious?

- Is there any relation between the ATR and Christianity in Zambia?

- What is the attitude of Pentecostal Christian churches towards the ATR belief in spirits and healers-diviners' practices? Are they tolerating or rejecting it? Do they enculturate the gospel with preChristian beliefs?

\section{Methodology}

To establish the presence of the ATR and its contacts with Christian churches, the authors applied methodologies from several fields: Religious studies, anthropology, and ethnography such as participant observation, indepth structured, semi-structured, and unstructured interviews that sparkled a spontaneous flow of information. A constant comparative method, categorizing and comparing qualitative data, derived from an everyday experience was applied. The phenomenological approach was used to understand and analyze the consciousness of religious leaders and other believers to gain primary data from the view of an insider. The authors - being Polish and Zambian respectively - have combined their native African and Western cultural and academic backgrounds to present data in the most objective way.

Information about pre-Christian beliefs, especially contacting spirits, was acquired from other researchers' publications, church leaders, and ng'angas - healers, spiritual healers and healers-diviners, responsible not only for the healing and wellbeing of their communities, but also for keeping ancient traditions and passing them down the generations. Some of them perform priestly duties, while others belong to organized groups. Associating all healers-diviners within one organization, has been opposed by many, as they believe their powers have a spiritual and/or divine source and hence they do not want to be 'under a human organization', misunderstood or labeled witches or witch-doctors (Twumasi 1985:71). However, there are several 
organizations like the Ethical Psychologist Association of Zambia (EPAZ), The Fingers of Thomas (Roman Catholic organization supporting ng'angas), and the biggest of them all, the Traditional Health Practitioners Association of Zambia (THPAZ, founded in 1978). According to the THPAZ president, Rodwell Vongo, approximately 40,000 healers belong to their organization, of which $55 \%$ are women. They are scattered all over the country, belonging to different churches, and practicing four kinds of healing: Herbalists, birth attendants, faith-spiritualists/healers, and healers-diviners. The latter two are believed to work with spirits such as mizimu, mashawe, ngulu, and vimbuza, and they also use herbs (Interview, Patrick Mulenga: August 2021). This information is also reported by other researchers like Cheyeka, Hinfelaar, and Udelhoven (2014:1038), as well as Sugishita (2009:436, 442).

The participants (52 people of whom 10 were females) were interviewed in their natural environment, their homes and meeting places of their choice in Lusaka, the capital city of the country, and Choma, Livingstone, Monze, and Siavonga, all located in the Southern Province. Most of the participants (apart from priests and pastors) lived in low density and poor residential areas of towns and had an income lower than average. They came from different Bantu ethnic groups, but were all born, raised, and trained in Zambia. The participants were contacted via the healers' organizations that they belong to and via local artists, and were also found on-site in local markets. They had to be healers-diviners, not healers-herbalists, and had to have clients who came for consultation, not only in health-related problems, but also other aspects of life. When it was possible, their clients were also contacted to verify the scope of the services that the healers provided for them. The Roman Catholic priests, cooperating with healersdiviners, were found before the field research and contacted via e-mails.

5 EPAZ was established in 2010 by Patrick Mulenga, academic, psychologist, and therapist in Lusaka. His grandmother was a healer-diviner, rejected by a Roman Catholic priest who considered her a pagan. Even though the family suffered, Mulenga decided that some of his patients needed more than therapy or psychiatric medicines, they needed a holistic approach, rooted in African tradition. Hence, he organized a group of healers, including spiritual and divining, to treat patients according to their needs. Now the group consists of almost 20 healers, five of them women, belonging to different churches and practicing traditional medicine (Interview, Patrick Mulenga: August 2021). 
Pastors were found on-site during Sunday services and working hours in their offices.

\section{Zambian Forms of Pentecostalism}

In Zambia, Christianity is referred to in terms of Church Mother Bodies or Church Umbrella Bodies. There are three traditionally and widely recognized Church Mother Bodies in Zambia: The Zambia Conference of Catholic Bishops, the Council of Churches in Zambia which incorporates classical mainline Protestant churches such as the Anglican Church, the Reformed Church in Zambia and many others, and the Evangelical Fellowship of Zambia (EFZ). On January 8, 2001, the Independent Churches of Zambia mooted Bishop David Masupa as head of an umbrella body to bring together charismatic churches, ministries, fellowships, worship centers, and others which did not belong to the EFZ. The umbrella body was officially registered with the Registrar of Societies on October 29, 2001 (Cheyeka 2008:27).

Much has been written about Pentecostal churches in Zambia, but what has often not been dealt with, is the distinction between 'charismatic' and 'Pentecostal'. Many scholars have simply opted to use 'Pentecostal' or even 'Evangelical' in some cases to refer to both. Ordinary Zambians who belong to Pentecostal and/or charismatic churches are blind to the differences (historical and theological) and identify themselves in the vernacular discourse as nifwe ba Pente (we are Pentecostals). While prophetism is a popular form of Pentecostalism in Zambia, as elsewhere in Africa, it does not strike as a distinct variety of Pentecostal Christianity, but rather as a style of leadership in Christian ministries that deeply borrows from African traditionnal diviners and herbalists. Analytically, it fits as a sub-wave into neo-Pentecostalism.

Membership of Pentecostal churches is varied and fluid depending on the location of the church in a town or rural area. In low density areas in the cities and towns, these churches are patronized by the working class, businesspeople, and students. Some churches are local grassroot ministries with a congregation of less than hundred, others are well prospering businesses (Mildnerova 2014:18-19). The rich are drawn to the pastor with the message of prosperity and health, while the pastor himself/herself is wealthy. Bishop Joe Imakando of the Bread of Life Church belongs to the Pentecostal 
elite in Zambia and his churches are big and built close to shopping centers. $\mathrm{He}$ is the first Pentecostal preacher to have built a megachurch, the Blessings Centre with a sitting capacity of 10,000 people. Arguably, he is the exemplar of the prosperity gospel in Zambia.

In 2016, according to Kaunda (2016:31), Imakando's church had over 12,000 members at the Blessing Centre. He has also established 112 churches outside Zambia. It is likely to be the case that Imakando is the richest pastor among the well-known pastors such as Bishop Joshua Banda, Pastor Nevers Mumba, Bishop Peter Ndhlovu, Pastor Joseph Kazhila, Pastor Bernard Nwaka, Bishop George Mbulo, and Bishop Edgar Ng'ambi, among others. Imakando preaches the prosperity gospel dogma which blends Pentecostal revivalism with elements of positive thinking and making the words of the Bible to the listeners become effective through the act of the anointed preacher speaking to them (Coleman 1993:355; Kroesbergen 2017:5).

Pentecostalism has found its home in mainline churches, especially in ways of praying and preaching by priests, reverends, and others. To this end, Asamoah-Gyadu has coined the term 'Charismatisation' or 'Pentecostalisation' of Christianity in Africa to refer to an attempt by mainline churches in Africa to adopt or accommodate some Pentecostal elements (AsamoahGyadu 2013:11). This 'Pentecostalisation' of Christianity in Zambia has been going on from the 1980s and coincided with the economic recession and the formation of neo-Pentecostal churches (Cheyeka 2006:54-71). Even more significant is the ability of Pentecostalism in Zambia to appropriate both the indigenous and contemporary Zambian/African cultures' anthropocentric focus. In other words, Pentecostalism has thrived on the fertile grounds of Zambian traditional cosmologies by appropriating notions of salvation within the framework of their inherently religious and anthropocentric cosmology (Sakupapa 2016:762).

What is debated by some scholars in Zambia is whether those who join Pentecostal churches from mainline churches actually convert to the Pentecostal churches that they join. This is because there is a high degree of social fluidity across denominations in the country and to this end there is an agreement among researchers that most people jump from one church to another in search of wealth and health - they are called 'church hoppers'. In doing so, they do not only follow the name of the church, but also the pastor if the latter has a reputation of healing, prophecy, 'standing in the gap', and mediating blessings (Cheyeka 2014:240-241). 'Across denominations in 
Southern Africa there is high degree of fluidity because individuals are relatively free to participate in multiple religious traditions and congregations over the course of their lifetime, or even in the course of their day-to-day lives' (McClendon \& Riedl 2019:55).

The Pentecostal message differs from traditional churches, such as the Roman Catholics and other old churches: It does not focus on the reward in heaven, but on wellbeing on Earth. By preaching the hope of wealth and health during one's worldly life, they attract people who want the betterment of their lives, and those who are already rich and happy and want to keep it that way. Pentecostal sermons ask listeners to transform their mindsets and embody that transformation in their actions - to live as if the material change had already happened (McClendon \& Riedl 2019:17). Alfred Kapepe, pastor of Day Spring Christian Ministry argues: 'As Pentecostals, we tend to speak to real issues. Sickness is not a matter of hospital but also prayer, so we combine the two. We pray for healing as the patient takes medication from hospital. People also want to know what is happening in their lives, so they come for prophesy to ascertain what it is that God is telling them in their lives' (Interview, Pastor Alfred Kapepe: July 7, 2021). This way of thinking is similar to the roles that healers-diviners have always performed in the society: They deliver certain results in both health and material issues. They are approached by people to fix their problems and, as they usually call upon ancestral spirits, the Holy Spirit, or Jesus Christ, their healing, combined with prayer, fulfils the same role as Pentecostal pastors who give hope and perform healing rituals. In sharing his reasons for the change of affiliation from the Roman Catholic Church to Abundant Life Fellowship Church, Joseph Siwo stated: 'People want quick fixes in life. People want to prosper, they want to find a husband or wife and they find answers in Pentecostal churches' (Interview, Joseph Siwo: July 2021). Similarly, Pastor Michael Mvula of Bible Gospel Church in Africa (BIGOCA) narrated, 'Pentecostal preachers promise immediate results. People look for things that address immediate concerns' (Interview, Pastor Michael Mvula: August 11, 2021). 


\section{Pre-Christian Beliefs in Zambia: The Importance of Spirits and the Belief in Witchcraft}

Southern African religions, including those in Zambian, were passed down for centuries from generation to generation. Early missionaries noticed that Bantu life was essentially religious, being visible in the family and clan life and in all local policies. ATRs have always been 'communal, an affair of the family, the clan, the tribe rather than of the individual' (Smith 1966:14). In this way, the whole community was responsible for maintaining good relations with spirits and deities. The ATRs are based on the concept of 'force' a dynamic vital energy that pushes life forward (Smith 1966:17-18). This life force is represented by spirits, both ancestral and environmental. The belief in spirits is the main ATR factor present, even among declared Christians.

The Bantu belief system was mostly recorded by missionaries and anthropologists of European descent, at the early stages of the colonial superiority. However, they provided valuable information. Even today, the oral tradition is alive and transmitted from elders and spiritual leaders to the next generations. It consists of the events and beliefs told by previous generations and of facts conveyed by elders to their listeners - or rather their interpretation of important facts like tribal events or natural disasters. On a daily basis, the importance of myths and tales is validated by the believers once they stop believing in a myth or tale, they stop being part of the culture and disappear. Sometimes something that was once believed in, is rejected. Pre-Christian beliefs in Zambia were influenced by the peoples' surroundings, resources, and spiritual needs which were strictly connected with their natural environment. Hence, the natural world has always been perceived as spiritual. Certain aspects of it like waterfalls or trees were thought to have spirits of their own and are still believed to be sacred. People therefore relate to their natural environment in a religious way. For example, they treat a tree like a mother and take its bark, some leaves, or twigs to make medicines, but never an amount that could harm the tree, and they never consider cutting it down 'because you don't cut the mother' (Turner 2002:155).

Each of the 73 Bantu ethnic groups in Zambia has their own customs and rituals, also religious beliefs. As ' $\mathrm{t}$ ] raditional Zambian religions have served as the bedrock of belief in the Christian God' (Cheyeka 2015:564), Christianity was built on the belief in spirits, therefore accepting the Holy Spirit as the highest form of spirit. This pre-Christian belief lingers within 
ATR Christianity. Additionally, the belief in the powers of sacred places (for example shrines inhabited by influential spirits) made it easy to understand the concept of building and attending churches. Early missionaries reported that ancestral spirits were treated like living entities, just invisible but still influencing their families: '[T]he soul slips out of the body, and talks, hears, travels, and capers entirely on its own account' (Willoughby 1928:6). Contemporary researchers report the same attitude: 'Africans are acutely conscious of spirits' (Turner 2002:150). They do not treat them as metaphors but as really existing entities. The belief that very little in life happens by chance and without some spiritual reason like spirits' interference, is very popular (Turner 2002:151; Taylor 2006:28). The reports about experiencing spirits, are broadcasted by radio stations, even secular ones. They present testimonies of pastors who helped to cast out evil spirits and of those healed (Udelhoven 2016:29). Spirits are remembered within families and are also, especially in rural areas, invoked for ceremonies like bringing rain, healing the sick, and puberty rites. Often food offerings for ancestors are left in local shrines or at the doorstep. Our participants pointed out a variety of spirits: Ancestors, evil spirits called by witches, the Holy Spirit, and nature spirits.

Spirits called ngulu, believed in by the Bemba, represent territorial spirits inhabiting places of special meaning like waterfalls and big, strange rock formations. Shrines are often built in such places and rituals are performed there (Taylor 2006:26, 28; Mwale 2015:8). Spirits of nature are believed to be responsible for dietary taboos, illnesses, and even madness, and they can also bestow blessings and extraordinary abilities on the faithful. In certain regions, spirits and their powers differ. They also answer to different rituals and offerings, depending on the cultural background, while the belief in their presence is popular in every part of Zambia (Udelhoven 2016:34-35).

The 'Mother Nature' rhetoric was created in respect for the environment, now even strengthened by the results of global warming, like desertification and the disappearance of local fauna and flora, causing the destruction of important food supplements and food insecurity (Mwale 2015:4). Even Christianized Zambians in the $21^{\text {st }}$ century still try to secure rainfall and crops by rituals coming from ancient times, and ask ancestral and environmental spirits for help. It is done with food sacrifices left at shrines to secure rain by the Tonga, as well as the Kuomboka ceremony during which the Lozi actually run away from the rising waters to avoid floods in the 
future, and other rituals (Mwale 2015:8, 10). Rituals include 'dances, songs, crafts, and artefacts that have been passed down through the generations', many of them to appease the spirits of nature (Mwale 2015:7).

In the ATR, there is a concept of the eternal god-creator among the Bantu in Zambia, for example the Lozis' god, Nyambe, the Tongas' god, Leda or Leza, the Bembas' god, Lesa, and the Chewas' god, Chiuta. These deities do not interfere with human affairs. Worldly problems and requests are discussed with ancestors - a belief very common among all Bantu peoples in Southern Africa. Ancestors are once living people, therefore their influence can be both good and evil. They may feel offended and punish their living relatives or they can be grateful for offerings and being remembered, and bless them (Smith 1966:65-68; Taylor 2006:29). The Bemba term used widely by other ethnic groups for ancestors is mupashi (pl. mipashi), which is the term that they are using for soul, the immortal spiritual component which can be contacted after a person's death. It is connected with a person's heart (in Tonga, Chewa, and Nyanja it is called mzimu). Everyone is born with the mupashi. Later people develop their own personal habits and ways of being that are called imibele (in Tonga, Chewa, and Nyanja it is called mzimu wa umuthu), which grows and changes with experiences gained during one's lifetime. These elements make a person whole.

This approach to selfhood is fundamental for the holistic style of healing. Nature spirits can also have mipashi, which shows that humans and the rest of the natural world are connected. In the Bible, translated to Bemba, the Holy Spirit is called Mupashi wa Mushilo (the spirit set apart) (Udelhoven 2017:132-134). Spirits are not worshiped, they are venerated. People do not pray to spirits, they rather talk to them and ask for advice or help. One healer-diviner averred: 'Like in old times, spirits are among us. Before we became Christians, we asked them for help because gods were far away. Yahweh is far away too but he sent Jesus to us. So we pray to Jesus and then call upon spirits for help. I am sure that spirits are blessed by Jesus, they are closer to him than living people and that is why they can help us. They can transmit God's wisdom and advice' (Interview, Participant A: August 2021) ${ }^{6}$.

Many Bantu people believe in witchcraft. Witches (both male and female) are believed to cause harm, while healers-diviners are supposed to be

6 He was a male healer-diviner from Siavonga. 
good and helpful ${ }^{7}$. Sugishita's research, conducted in the Kalingalinga township, indicates that over $70 \%$ of the inhabitants believe in umfiti, the Nyanja concept of witchcraft. When something happens to them, they turn to healers-diviners for help (Sugishita 2009:440). Though that research was done on a small group, it shows the scale of the belief in the possibility of being bewitched ${ }^{8}$. Over $70 \%$ of the participants declared that they have already been fighting witches' powers. Some of them are Jehovah's witnesses, while others are Pentecostals or Roman Catholic. Some were involved with ancestral spirits, while others prayed to the Holy Spirit for help.

The belief in spirits and curses by witches is so strong that even some Catholic priests believe in possession by evil spirits caused by witches, and try to help 'afflicted' people. Emmanuel Milingo, Archbishop of Lusaka, answered the needs of thousands of people who believed to be oppressed by evil spirits and celebrated healing masses during which he did exorcisms. He believed that people's faith in both possession and freeing from it influence their lives. Hence the church should answer these needs by providing methods of relieving the pain and fear by means of masses, rosary, blessings, and holy water (Udelhoven 2016:28).

\section{Who are Healers-Diviners? The Calling of Healers-Diviners}

According to the World Health Organization (WHO) (WHO 1976), an African traditional healer is a person who is recognized by their community and other communities as "competent to provide health services, using plant,

7 Some people feel confused when describing healers-divines. For them, the ng'anga stopped being a doctor who cured the results of witchcraft, and became doctors who are also witches, and who can both heal and harm (Sugishita 2009:441). The term 'witchcraft' is often wrongly used for healers-diviners. It has a derogatory meaning. It is also problematic for anthropologists: 'It is not clear that there is any perceptible resurgence of witchcraft in Zambia; however, it does appear that witchcraft itself has been modernized in the sense that it is deployed today in ways that reflect contemporary life and social and political forces' (Taylor 2006:26). As people are scared of witches and accuse them of wrongdoings, the term should not be applied to benevolent healers-diviners.

8 The Witchcraft Act created under the British rule prohibits witchcraft and the promotion of it. It is still a valid law in Zambia and can be used in court (Republic of Zambia. n.d.). 
animal and mineral substances as well as other methods based on social, cultural and religious background. [Traditional healers] utilize the prevailing knowledge, attitudes and beliefs in the community about physical, mental and social well-being, and the causes of a disease and disability" (Nelms \& Gorski 2006:184). Zambian healers-diviners fit the WHO's definition: They provide health services that are based on herbal cures, religious and tribal beliefs, and the traditional understanding of wellbeing. They are strongly grounded in their communities and draw not only from their training but also from the knowledge about the people they serve and the knowledge about their beliefs. This is crucial because in Southern Africa, sickness is the result of religious, moral, economic, and social influences on a person who, in result influences their own psychological and physical state, which then causes the sickness. Most of the patients are Christian but entwined with preChristian beliefs in spirits. Hence the healing process usually involves prayers to Jesus or the Holy Spirit and a calling upon the ancestors.

A traditional healer in Zambia is called $n g$ 'anga. They are herbalists, diviners, and/or spiritual healers. Healers-diviners are believed to be called to their vocation or profession by spirits. The participants stated that one can choose to be a healer, but to become a spiritual healer or a diviner one must be called by spirits who communicate through visions and dreams (cf. Schoffeleers 1994:78). These spirits are then asked by a healer to help them to help their patients. They advise how to make medicines of red clay and plants and how to perform rituals that include drumming, singing, dancing, and praying (Schoffeleers 1994:78; Turner 2002:155-156, 162). Many participants related that they were also guided by the Holy Spirit.

As Christians, the participants narrated that spirits are helping them because it is God's will and hence all churches should support them and not fear them. They also stated that churches are unfortunately afraid of spirits because priests do not understand that the spirits are not competing with God: Maria stated, 'We do not pray to spirits, we talk to them. Priests should not be afraid of them because we do not want them to replace God. God is God, he has billions of people to look after. Spirits are familiar, they help locally' (Interview, Maria at Monze: August 2021). 'Spiritual work is Godly, only God can heal, hence it is only his power to use healers as tools to help people' (Interview, Vongo: August 2021). Maria adds, 'It is God who sends spirits and dreams and visions. If spirits call us, then it must be God's will, and it must be good' (Interview, Maria at Monze: August 2021). Such beliefs 
were reported from the early days of academic research in Zambian religions: '[D]reams are regarded as common channels of divine communication' (Willoughby 1928:91). The spirits have always been believed to enter people and speak through them (Willoughby 1928:106). People have always considered prophets or medicine men as the ones who convey messages from spirits and have abilities to heal, and to possess 'a predisposition to ecstasy, day-dreams, and visions' (Willoughby 1928:114). These beliefs have survived the Christianization process and are still present in modern Zambia. The calling of healers-diviners consists of dreams, visions of ancestral spirits or the Holy Spirit, and very often of a sickness that cannot be treated by Western medicine. The sickness is not the same as in the case of sangomas in neighboring countries, where it is a must - the participants claim that refusing spirits ends up in sickness and sometimes even in death.

Working with spirits can take different forms as different kinds of spirits are helping healers. The recounts of the calling include contacts with ancestors and animals that are considered sacred in many Bantu cultures, like river snakes ${ }^{9}$. Joseph started his calling by receiving dreams at the age of 18 . He received visions of a green snake that lived in a river. The dreams were so disturbing that he recounted them to his grandfather who was a healerdiviner. He interpreted them as the calling. Joseph rejected the calling and as a result he got sick. Doctors could not find the reason and could therefore not give him treatment. He went to Dr Siwila, a well-known healer-diviner in Lusaka, who confirmed the diagnosis of the calling. After two weeks of herbal treatment, Joseph started recovering, although the dreams continued. New spirits joined and forced him to accept his life role. Joseph learned from both the spirits and Dr Siwila. He does not call on spirits, they come to him in times of need and help him to treat patients (Interview, Dr Siwila: August 2021).

Ester works with the Holy Spirit. At the age of 21, she started receiving dreams in which she traveled and met healers and medical doctors, and she met her late father who was a known healer-diviner. She also got sick. At hospital, doctors could not find any reason for her physical and

9 Snake worship (ophiolatreia) is one of the most universal forms of worship in the world. The Southern Bantu are specifically worshiping water snakes. Because wisdom is compared to water, water snakes embody the flow of knowledge from spirits to the novice healer-diviner (Wreford 2008:75-76). 
mental weakness, so she contacted a spiritual healer. He recognized her symptoms as the calling to become a healer and became her teacher. During the training, her father's spirit left her and she started feeling the Holy Spirit who now shows her visions of sickness in people and helps her to treat patients. She uses the Bible to assist her patients. She belongs to the Mutumwa Church of Zambia (Interview, Ester: August 2021). The Mutumwa Church is a Pentecostal church within the Zion tradition and a medicoreligious body that started in the 1930s. The term 'Mutumwa' refers to 'one who is sent' - an apostle. Whereas the congregation considers Jesus as a healer, it is not surprising that contacting mipashi and the Holy Spirit is accepted and practiced. The Bible is used for divination and is put on the head of a patient during the healing process (Dillon-Malone 1983:205; Mildnerova 2014:18). Ester heals within her church with the blessings of her pastor.

Being called by spirits is the story most often told by $n g$ 'angas, also those who do not contact spirits. Four healers-participants are Jehovah's witnesses who reject the belief in a soul that lives after one's bodily death, based on Ecclesiastes 3:19 ${ }^{10}$. Even though their religion strictly forbids any contacts with spirits, they agree that some people experience the spirits' presence. They also believe that not all spirits are evil, as some of them may call people to be healers and be helpful (Interview, four healers: August 2021).

\section{The Role of Healers-Diviners}

Healers-diviners mediate between worlds: Profane and sacred, physical and spiritual, herbal, and holistic healing and allopathic medicine (Western) in the African reality where natural and supernatural realities have been intercomnected for ages. They are asked to deal with all problems that may have a spiritual cause, like sickness, unemployment, an inability to find a spouse,

10 The belief is based on Ecclesiastes 3:19: Surely the fate of human beings is like that of the animals; the same fate awaits them both: As one dies, so dies the other, and 8:8: As no one has power over the wind to contain it, so no one has power over the time of their death. The Jehovah's witnesses understand these verses as a proof that humans do not have souls different than animals. Both die physically, and human bodies can be raised from ashes by God. 
and general misfortune which can also be perceived as a kind of sickness. Maria claimed: 'Jesus was asked for the same: To expel evil spirits and to heal' (Interview, Maria at Monze: August 2021). They are expected to guide their communities and have a good relation with all spirits and deities to secure their protection. They serve as doctors, psychologists, and keepers of ancient wisdom, passing down traditions and rituals and their traditional educational system which supplements the Western one offered in government schools. They should 'bring clarity because of [their] access to the hidden world, through special eyes, dreams, visions, gifts of telepathy, methods of divination or other means' like herbal medicines (Udelhoven 2017:124). Their modes of healing are not only based on herbal medicines but include consultations with spirits. They often specialize in some fields, for example women or children diseases, impotence, and snake bites. They are not confided to provincial towns and villages but work in big cities and often use modern methods of reaching clients, for example the press, radio, and internet (Mwale 2015:7, 9; Udelhoven 2017:123).

In pre-Christian times, Ng'angas - herbalists, healers-diviners, and spiritual healers - were the most respected members of their communities. They were not only trained healers but also the advisors to leaders and chiefs. This is one of the reasons why Christian churches feared (and many still do) their social importance. Named 'witch-doctors' by colonialists, they lost their privileged social position, but they are still called for help in cases of health and life problems. It is not only the result of the tradition. $\mathrm{Ng}$ 'angas treat people holistically which means that they examine the psychical health, family, and social situation of the sick person: A person can only be healthy when there is a balance between body, mind, and soul. A patient is examined in their social contexts: If a person is rejected by their community or abused by the family, then they cannot be healthy and feel well. Added to that, all affairs with the ancestors should be in order. Life and death are not separated as in the Western way of thinking. Life and death form a unity and as such are part of familial relationships and the emotions caused. For these reasons and the fact that in the rural areas, Western medicine is scarcely available and too expensive, traditional medicine and its spiritual elements are in high demand (Twumasi 1985:17-20; Nelms \& Gorski 2006:184; Udelhoven 2017: 123). The work of the $\mathrm{Ng}$ 'anga is diagnostic, therapeutic, and prophylactic as in the case of any healer in the world. Imbuwa related, 'Especially prophylactics usually requires some sort of divination and spiritual guidance. Our 
role is to give people health and hope. I dream about my patients and plats which will help them, they know spirits always help me. This is our African culture, and this is why patients trust me' (Interview, Imbuwa at Livingstone: August 2021).

Medicines called umuti are made of different parts of trees, shrubs and other plants, usually being mixed with water, for someone to drink ${ }^{11}$. Umuti can be mixed with cishimba (plural: fishimba), an animal ingredient that is supposed to enhance the spiritual power of the medicine. The ingredients can be the fat of a python or lion, insects, or fish. Such medicine is often administered with the order to follow a certain taboo, usually a dietary one, to the end of the patient's life. These procedures link the patient with a spirit of a certain life force that helps healing the patient. It is also believed that umuti can be used by witches for evil reasons, especially if cishimba was taken from a cemetery - it can be from a plant, an animal, or a human (Udelhoven 2017:125-126). This belief explicitly shows the connection that people still feel with Mother Nature. Says Malumo, 'The medicinal plants were created by God and God gives us knowledge through spirits. Every church should understand it. Without Nature, our Mother, we are lost, we could not help people cursed by witches and seriously sick. Thankfully, my church understands it and pastor comes to me for help and sends sick people to me' (Interview, Malumo at Livingstone: August 2021) ${ }^{12}$.

Sometimes healers-diviners perform priestly duties like praying at funerals, 'sending' the dead person to the ancestors, and exorcising, which does not make them popular among Pentecostal pastors who prefer to keep priestly activities and healing procedures to themselves. They are also asked to perform the naming ceremony, though this tradition is in decline. Traditionally, a name should be given after a special ancestor and secure this ancestor's help. If a child gets sick after the naming ceremony, it might mean

11 The term umuti refers to traditional medicine. It is a popular term in Bantu languages and is also used by ethnic groups in neighboring countries, for example by Zulus in South Africa. Umuti is supposed not only to heal the body, but also to enhance human strength and general wellbeing, to mediate between physical and spiritual worlds and bring 'an awareness of the connectedness of the human person with the cosmos, and specifically with certain plants and animals that can mirror human conditions' (Udelhoven 2017:125).

12 Malumo belonged to the Pentecostal New Apostolic Church. 
that the wrong ancestor was chosen and that the name should be changed (Udelhoven 2017:135). Ng'angas, in addition to healing, also create charms, lucky potions, detect witches, and repel curses and unwanted spirits. They take part in rituals to help crops grow, fishing, hunting, and trading, and are 'centrally concerned with the promotion of good fortune' (Schoffeleers 1994:75). All the participants supported this information. This is understandable, as sickness in Africa is considered to be a misfortune and often has esoteric reasons. During the last century, many researchers came to the conclusion that the more serious a misfortune is, the more mystical reasons there are, and the more healers-diviners are sought after (Schoffeleers 1994: 76; Evans-Pritchard 1937; Gluckman 1965; Turner 1967; Janzen 1978).

\section{How do $\mathrm{Ng}$ 'angas Meet with Christianity?}

'Do $n g$ 'anga and Christianity meet?' was a question asked to all participants. The majority of Pentecostal pastors answered 'no', while the healers-diviners answered positively. These contradicting answers were given in all five towns. Healers-diviners see no contradiction in being both Pentecostal Christians and communicating with spirits. Healers and their clients have no problem to incorporate Jesus into their beliefs and work. In fact, most of them are Christians ${ }^{13}$, and asking Jesus or the Holy Spirit for help before divination or healings poses no problem for them.

Clients accept spirits, both ancestral and the Holy Spirit, in dreams, visions, and the process of helping. Julius recalls, 'My patients want to pray with me. They know that Jesus was our ancestor too. He called us brothers and sisters, and God our father. So he sends his wisdom to healers-diviners. God sends spirits. The Holy Spirit, Jesus, and ancestors work together through diviners' (Interview, Julius at Livingstone: August 2021) ${ }^{14}$. Schoffeleers recalls situations where 'Christ is often referred to as $n g$ 'anga because this is an image that the audience intuitively understands and the same time is seen as rooted in scripture' (Schoffeleers 1994:79-80). In Zambia, Mutumwa

13 Researchers already reported a vast Christianization among $n g$ 'angas during the 1990s (Schoffeleers 1994:82).

14 The same thoughts were expressed by most healers-participants from Lusaka, Livingstone, Monze, and Siavonga. 
or apostles' churches consider Jesus as 'the true shiganga or healer' and they believe that they continue his healing work (Schoffeleers 1994:79-80).

The acceptance of healers-diviners and their abilities not only depends on a church's credo, but also on the personal views of pastors. Some show an open acceptance, like the Mutumwa Church of Zambia, the Back to Eden (BtE) branch of the Seventh-Day Adventist Church (SDA) even gives certificates that 'legalize' healers-diviners' work, while some grant a semiopen acceptance like the Zion churches, although the majority reject them.

Zion churches form the largest group of prophet-healing African Initiated Churches in Africa and fuse African traditions and beliefs. They focus on prophetism, spiritual healing, and religious syncretism that incurporates the belief in ancestral spirits into Christian teaching (Mildnerova 2014:8, 10). This attitude is based on

the understanding that when Jesus left his disciples and ascended into heaven, he said that he would not leave his disciples alone but would send the Holy Spirit to guide them and lead them (Lk 24:49) ...possession by the ancestral spirit is recognized but it is transformed by faith and prayer giving way to the Holy Spirit from Christ who gives the gift of prophecy (Kelaotswe 2005:110).

In this way, native African belief is incorporated into Christianity, while the power of the Holy Spirit is combined with that of the ancestors. In Zion churches, healing is achieved by the power of the Holy Spirit who transmits its powers through the laying-on of hands, prayers, the use of holy water, and drinking special infusions, which help cleanse the body and mind of sicknesses caused by physical and esoteric reasons like curses from evil spirits or witches. Exorcism is also practiced to get rid of evil spirits or devils. As the body can be possessed by bad spirits, it can also be healed by the possession of the Holy Spirit (Mildnerova 2014:17).

Our research showed that some Pentecostal pastors seem to accept the fact that spirits visit healers because this is something that healers cannot control. However, they do not accept calling upon spirits and asking them for help. Pastor Mvula from BIGOCA argues: 'In fact, we don't cross paths because as Pentecostals, we see demonic and satanic powers in traditional healers and our members are warned against consulting traditional healers and diviners' (Interview, Pastor Michael Mvula: August 11, 2021). Pastor 
Dickson Mbulo, the founder of Christ Assembly Pentecostal Church in 2017, relates, '[W]e don't accept diviners because to us Jesus Christ is the only healer; these diviners could be false prophets' (Interview, Pastor Dickson Mbulo: August 2021).

Some healers and diviners, calling themselves profitas, have already formed churches. According to Pastor Kapepe of the Day Spring Christian Ministries, they present themselves as 'Charismatic Pentecostals' and mix muti and prayer by selling anointed water, oil, soap, ball point pens, fruit, and other things. They even charge consultation fees to their clients. Pastor Kapepe further shared that there was no relationship between his church and profitas, and members are discouraged from visiting the churches of profitas, although some still do and sometimes approach him to accept some profitas as partners because they are anointed (Interview, Pastor Alfred Kapepe: July 7, 2021). Rev Chalton Kakena of the Pentecostal Holiness Church City of God claims: 'The Bible does not allow us to mix with diviners. They remain diviners although they are now claiming to be prophets or profitas. Our church and the church as a whole believe in divine healing. We do not know where these profitas get their power from. I can also tell you that we discourage our congregants to consult diviners because their powers are not from God. However, it is difficult for us to control and monitor our congregants' (Interview, Rev Chalton Kakena: August 2021).

Other pastors reject any possibility of practicing contacts with spirits. Pastor Godfrey from the United Pentecostal Church of Zambia (a part of an international church), states that there are no healers-diviners in his congregation. If anyone of them comes to his church, he will be welcome but also asked to not speak about spirits. Pastor Godfrey agrees: As the base for his conviction that contacting spirits is wrong, he recalls Acts 8:9-12 about Simon the sorcerer who was condemned for his practices and saved when he embraced Christ (Interview, Pastor Godfrey at the United Pentecostal Church of Zambia: August 2021). The same explanation was given by pastors and elders from the Divine Harvest Church International, the Kingdom House International, the Livingstone Gospel Hall, and the SDA.

Kisco Mweemba, district pastor of 21 churches in the Livingstone region, asked about the SDA's Back to Eden branch to which many healersdiviners belong, recounted: ' $\mathrm{BtE}$ is supposed to be a branch that promotes traditional healing based on herbal medicines, but only medicines, no spiritual healing or divination. The SDA agrees with praying in the intention 
of healing. We believe that witchcraft exists, and that witches and demons can possess people. For such situations we have prayer groups who pray for the health of the congregation and for humankind. Only God can save possessed people, he is the ultimate healer'. He added that at the specific time, BtE was under scrutiny: 'The SDA looks carefully at them because some people seem to want to break from the SDA and form some sort of sect where divination is allowed'. Asked what he thinks about calling Jesus a $n g$ 'anga, he replied: 'Jesus is God's son, he is no $n g$ 'anga, he heals because he is divine' (Interview, Pastor Kisco Mweemba at Livingstone: August 2019).

This rejection is also reported by other researchers: 'Virtually all Christian ministries engaged in ritual healing object to the term ng'anga being applied to them [Jesus and the Holy Spirit]' (Schoffeleers 1994:81). One participant from Lusaka, two from Choma, three from Livingstone, and two from Monze explained that pastors fear that their authority could be lessened by healers-diviners. Participant B told us: 'Pastors say they get their powers directly from God, hence spirits are not needed' (Interview, Participant B: August 2021). Five other participants from Lusaka, Livingstone, and Siavonga claimed that their pastors secretly use their services but do not allow advertising it.

On the other hand, Vongo, the president of THPAZ, emphasizes that THPAZ cooperates with all the churches in Zambia, including the Pentecostal churches. He states that Christianity often fails when it comes to healing people and saving their lives, and it should be a joint effort by churches, doctors, and healers to help people. This is also the reason why he sends his patients to allopathic doctors when he cannot help them and receives patients from them (Interview, Vongo: August 2021). Many patients simply need to complete their therapy in traditional ways to feel safe and sure that no spiritual force can endanger them (Twumasi 1985:91-92). Participant C claims: 'White and African medicines meet, they complement each other, so does our ancient belief in ancestors' powers and Christianity. There is no sense in fighting each other' (Interview, Participant C at Monze: August 2021). The participants often deny the fact that some Pentecostal pastors refuse to accept working with spirits and try to convert healers-diviners on 'the right path'. 


\section{Conclusions}

Our fieldwork provided answers to the research questions. Zambian Christianity, including the Pentecostals, are influenced by the ATR beliefs in the presence of ancestral spirits. All our healer-diviner participants were Christians (except one), while census data show that the ATR is practiced by up to $10 \%$ of Zambians. There is no statistical data to establish how many churches allow pre-Christian practices, but the belief in spirits and witchcraft is so strong that all churches believe in it, though most condemn any contact with spirits.

Healers-diviners are believed to be called by spirits and they easily combine working with spirits with Christianity, no matter what their pastors' opinion is. They often incorporate spirits into the gospel, considering Jesus as the Great Ancestor: 'He called us all brothers and sisters, and said we had a father in heaven', is the most common explanation. They also believe that spirits cooperate with Jesus and the Holy Spirit, and their help is a gift from God - a sentiment shared by very few Pentecostal pastors.

Our research also shows that, in spite of the official doctrines, the attitude towards healers-diviners often depends on the personal beliefs and attitude of a pastor or priest, that even within one church organization the attitude can vary. It applies to global structural churches such as the SDA as well as local Zion churches. Many healers-diviners receive secret support from their pastors, other open acceptance. Those who feel the need to belong to a Pentecostal church with full acceptance of healers-diviners, are attracted by the BtE branch and do not refrain from the possibility of breaking from the main SDA body. They obviously need support which very few pastors grant them. However, even though Pentecostalism is purely based on the Bible, and most churches definitely forbid any spiritual work outside the church credo, we detected that some pastors prefer to keep their flock and then rather accept the healers-diviners. Others accept pre-Christian elements without complaint. Our participants who were healers-diviners, are hoping that accepting their practices is a growing trend in Zambia. The popularity of healers-diviners, the lack of fear of them, and the need to use their services allow the conclusion that no matter what priests and pastors declare from the ambo, Zambian Christians are not going to renounce their faith in the presence of spirits, neither do they plan to reject healers-diviners' help. Like in other countries of Southern Africa, pre-Christian beliefs in spirits linger within 
Christianity and there are no assumptions that the situation may change in the near future.

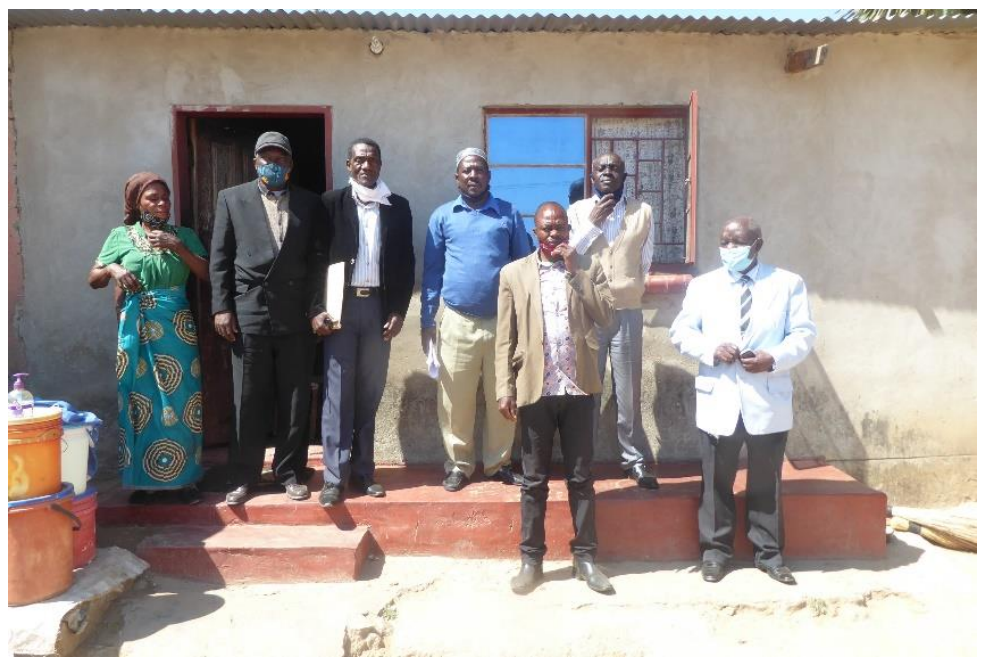

Healers from the EPAZ organization. They practice different kind of spiritual healing, including contacting with ancestral spirits and working with the Holy Spirit. They belong to different churches, including the Pentecostal church ${ }^{15}$.

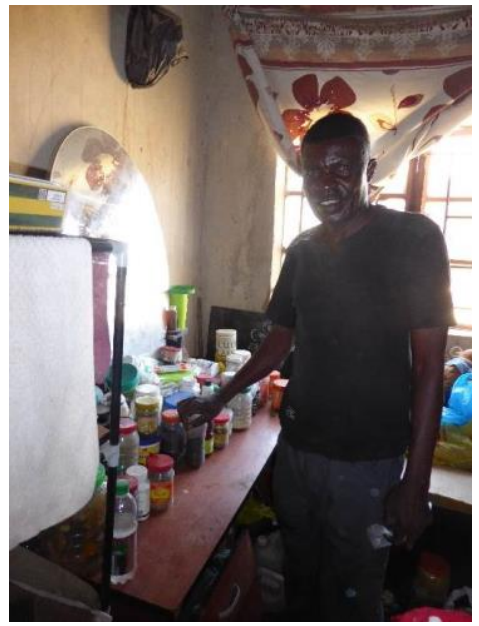

Pascal Tembo in his consulting office showing traditional medicines made from tree bark, roots, and herbs that he collects in the bush near Lusaka. He already trains his three-year-old granddaughter to be a healer. He states that she shows an incredible aptitude to remember how to make medicines and she is blessed by spirits. He belongs to the Winner's Chapel Pentecostal church where his vocation and work is openly accepted.

15 The consent from every member in both photos has been obtained. 


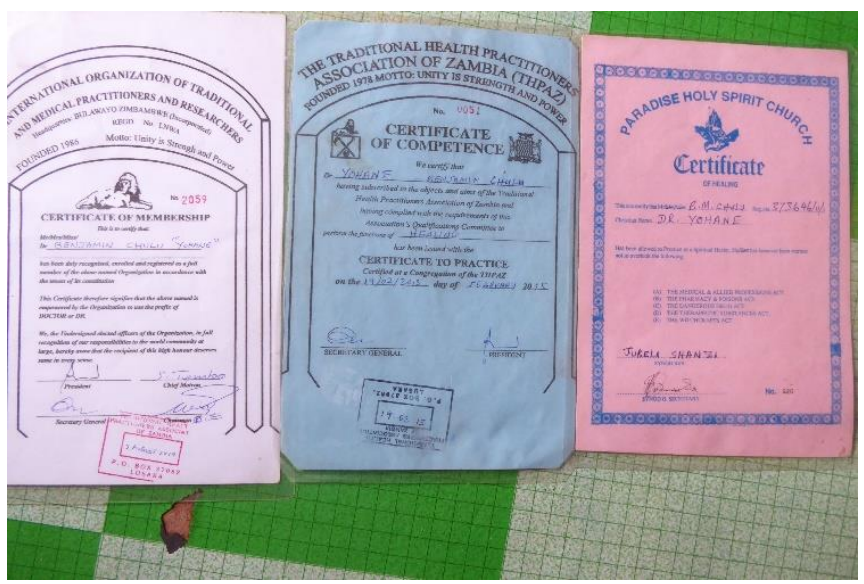

These certificates allow Benjamine 'Yohane' Chulu to practice as a traditional healer. On the right, the certificate from Paradise Holy Spirit Church (Pentecostal) approves his ability to practice spiritual healing.

\section{References}

ARDA (Association of Religion Data Archives). n.d. Zambia. Available at: https:// www.thearda.com/internationalData/countries/Country 245_2.asp. (Accessed on May 26, 2021.)

Asamoah-Gyadu, J.K. 2013. Contemporary Pentecostal Christianity: Interpretations from an African context. Eugene: Wipf \& Stock.

Cheyeka, A. 2006. Charismatic churches and their impact on mainline churches in Zambia. Journal of Humanities 5: 54-71.

Cheyeka, A. 2008. Church, state and political ethics in a post-colonial state: The case of Zambia. Kachere Theses no. 13. Zomba: Kachere Series.

Cheyeka, A. 2014. Zambia. In Riggs T. (ed.): Worldmark encyclopedia of religious practices. Vol. 4. $2^{\text {nd }}$ ed. Detroit: Gale Research.

Cheyeka, A. 2015. Conversion to Pentecostalism in Zambia. In Carmody, B. (ed.): Religious conversion: An African perspective. Lusaka: Gadsden Publishers.

Cheyeka, A., M. Hinfelaar, \& B. Udelhoven 2014. The changing face of Zambia's Christianity and its implications for the public sphere: A case study of Bauleni Township, Lusaka. Journal of Southern African Studies 40, 5: 1031-1045.

Coleman, S. 1993. Conservative Protestantism and world order: Faith movement in the United States and Sweden. Sociology of Religion 54, 4: 353-373.

Dillon-Malone, C. 1983. The 'Mutumwa' Churches of Zambia: An Indigenous African Religious healing movement. Journal of Religion in Africa 14, 3: 204222. 
Evans-Pritchard, E.E. 1937. Witchcraft, oracles, and magic among the Azande. Oxford: Oxford University Press.

Gluckman, M. 1965. Politics, law, and ritual in tribal society. Oxford: Basil Blackwell.

Haynes, N. 2012. Ambitious obligations: Pentecostalism, social life and political economy on the Zambian Copperbelt. PhD thesis, Anthropology Department, University of California, San Diego.

Holmes, T. 1998. Cultures of the world: Zambia. New York: Times Books International.

IHSN (International Household Survey Network.). 2010. Population and housing census 2010. Zambia, 2010. Available at: https://catalog.ihsn.org/index.php/ catalog/4124. (Accessed on July 22, 2021.)

Interview, Dr Siwila. August 2021.

Interview, Ester. August 2021.

Interview, four healers. August 2021.

Interview, Imbuwa at Livingstone. August 2021.

Interview, Joseph Siwo. July 2021.

Interview, Julius at Livingstone. August 2021.

Interview, Malumo at Livingstone. August 2021.

Interview, Maria at Monze. August 2021.

Interview, Participant A. August 2021.

Interview, Participant B. August 2021.

Interview, Participant $\mathrm{C}$ at Monze. August 2021.

Interview, Pastor Alfred Kapepe. July 7, 2021.

Interview, Pastor Dickson Mbulo. August 2021.

Interview, Pastor Godfrey at the United Pentecostal Church of Zambia. August 2021.

Interview, Pastor Kisco Mweemba at Livingstone. August 2019.

Interview, Pastor Michael Mvula. August 11, 2021.

Interview, Patrick Mulenga. August 2021.

Interview, Rev Chalton Kakena. August 2021.

Interview, Vongo. August 2021.

Janzen, J.M. 1991. 'Doing Ngoma': A dominant trope in African religion and healing. Journal of Religion in Africa 21, 4: 290-308.

Kaunda, C. 2016. The making of Pentecostal Zambia: A brief history of pneumatic spirituality. Oral History Journal of South Africa 4, 1: 15-45.

Kelaotswe O.N. 2005. Acceptance and rejection: The traditional healer prophet and his integration of healing methods. Boleswa Journal of Theology, Religion and Philosophy 1, $1: 109-122$.

Kroesbergen, H. (ed.) 2017. Neo-Pentecostalism in Southern Africa - some critical reflections. Wellington: Christian Literature Fund. 
Mackenzie, R. 1993. David Livingstone: The truth behind the legend. Chinhoyi: Fig Tree Publications.

McClendon, G.H. \& R.B. Riedl 2019. From PEWS to politics: Religious sermons and political participation in Africa. Cambridge: Cambridge University Press.

Mildnerova, K. 2014. African Independent Churches in Zambia (Lusaka). Ethnologia Actualis 14, 2: 8-25.

Mwale, N. 2015. African Traditional Religion in the context of climate change: A Zambian perspective. Journal of Humanities 13: 1-24.

Nelms L. \& J. Gorski 2006. The role of the African traditional healer in women's health. Journal of Transcultural Nursing 17, 2: 184-189.

Parrinder, E.G. 1954. African traditional religion. London: Hutchinson's University Library.

Republic of Zambia. n.d. The Witchcraft Act. Available at: https://www.parliament. gov.zm/sites/default/files/documents/acts/Witchcraft\%20Act.pdf. (Accessed on June 29, 2021.)

Sakupapa, C.T. 2016. Christianity in Zambia. In Phiri, I.A. \& D. Werner (eds.): Anthology of African Christianity. Oxford: Regnum Books International.

Sanneh, L.1989. Translating the message. New York: Maryknoll.

Sanneh, L. 1993. Encountering the West: Christianity and the global cultural process: The African dimension. London: Marshall Pickering.

Schoffeleers, J.M. 1994. Christ in African folk theology: The Nganga paradigm. In Blakhely, T., W.E.A. van Beek, \& D.L. Thomson (eds.): Religion in Africa: Experience and expression. London: James Currey.

Smith, E. 1966. African ideas of God. London: Edinburgh House.

Strayer, R. 1976. Mission history in Africa: New perspectives on an encounter. African Studies Review 19, 1: 1-15.

Sugishita, K. 2009. Traditional medicine, biomedicine and Christianity in modern Zambia. Africa 79, 3: 435-454.

Taylor, S.D. 2006. Culture and customs of Zambia. Westport: Greenwood Press.

Turner, E. 2002. A visible spirit in Zambia. In Harvey, G. (ed.): Readings in indigenous religions. London: Continuum.

Turner, V. 1967. The forest of symbols: Aspects of Ndembu ritual. Ithaca, London: Cornell University Press.

Twumasi, P. 1985. The professionalization of traditional medicine in Zambia. Urbana: University of Illinois Press.

Udelhoven, B. 2016. Unseen worlds: Dealing with spirits, witchcraft, and satanism. Lusaka: Fenza Publications.

Udelhoven, B. 2017. Seeing witchcraft. Journal of Global Catholicism 2, 1: 120-142. 
Vilakazi, A., B. Mthethwa, \& M. Mpanza 1986. Shembe: The revitalization of African society. Johannesburg: Scotaville.

Walls F.A. 1996. The missionary movement in Christian history: Studies in the transmission of faith. Maryknoll: Orbis Books.

Walls F.A. 2002. The cross-cultural process in Christian history: Studies in the transmission and appropriation of faith. Maryknoll: Orbis Books.

Willoughby, W.C. 1928. The soul of the Bantu: A sympathetic study of the magicoreligious practices and beliefs of the Bantu tribes of Africa. Doubleday: Doran and Company.

WHO (World Health Organisation). 1976. Declaration of Alma-Ata International Conference on Primary Health Care. Alma-Ata, USSR. September 6-12, 1978. Available from: $\quad$ www.who.int/hpr/NPH/docs/declaration_almaata.pdf. (Accessed on 21 August 2021.)

World Population Review. n.d. Zambia population 2021 (live). Available at: https://worldpopulationreview.com/countries/zambia-population. (Accessed on May 23, 2021.)

Wreford, J.T. 2008. Working with spirit: Experiencing Izangoma healing in contemporary South Africa. New York: Berghahn Books.

Zambia Census. 2010. Available at: http://www.zamstats.gov.zm/phocadownload/ 2010_Census $/ 2010 \% 20$ Census $\% 20$ of $\% 20$ Population $\% 20$ National $\% 20$ Analyti cal\%20Report.pdf. (Accessed on May 29, 2021.)

Dr Agnieszka Podolecka

Department of Linguistics

UNISA, South Africa

Department of African Languages and Cultures University of Warsaw, Poland agapod70@gmail.com Prof Austin M. Cheyeka Religious and Cultural Studies Department University of Zambia acheyeka@yahoo.co.uk 